\title{
ПРАВО: МІНЛИВИЙ КОНЦЕПТ У МІНЛИВОМУ СВІТІ (Всеукраїнський круглий стіл у Харкові)
}

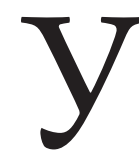

квітні 2019 року Національним юриАичним університетом імені Ярослава Мудрого та Націона ьною академією правових наук України за піАтримки журналу «Філософія права і загальна теорія права» було започатковано щорічний круглий стіл, присвячений фундаментальним проблемам юриспруденції. Останній було задумано як майданчик Аля професійного обговорення актуальних питань філософії права та загальної теорії права, що він міг би стати каталізатором розвитку віАповіАного інтелектуацьного простору.

Як виАається, запит на подібний проект зумовлений передусім сучасним станом правової Аумки. Так, сьогодні ми можемо спостерігати, як юриспруденція стає АеАалі більш практичною, фактично перетворюючись на технологію, знання «як». ВіАтак, постає питання: чи зацишається у сучасній юриспруденції місце Аля фунАаментацьного знання про право або Аля науки як такої, не кажучи вже про філософію? Той факт, що ініціатива організаторів Круглого столу знайшма широкий віАгук, замишає наАію на позитивну віАповіАь.

Спеціацьна тема цьогорічного заходу, винесена в заголовок огляду, мала на меті привернути увагу до парадигмальних змін у правовій науці у світлі сучасних викликів. Як змінюються наші уявлення про право у мінливому світі? Наскільки сучасним $є$ наш методологічний інструментарій? Чи потребуємо ми нової оптики? Як змінюється, власне, право на тлі радикальних змін у нашому існуванні та мисменні? 3 огляду на розгул насимьства в сучасному світі, екологічну катастрофу та розвиток технологій - чи є у права майбутнє? Водночас чи може право пережити постмодернізм, постметафізику, постгуманізм та інші тенденції, що ними може бути позначена духовна ситуація сучасності? Врешті-решт, яким критерієм ми послуговуємося, позначаючи вельми різноманітний досвіА поняттям «право»? Ці та інші питання стали предметом обговорення, уякому взяли участь більше 30 Аослінників із Аніпра, Києва, Аьвова, ОАеси, Полтави та Харкова.

\footnotetext{
${ }^{1}$ Наталія Іванівна Сатохіна, кандидатка юридичних наук, асистентка кафеАри теорії і філософії права, Націонацьний юридичний університет імені Ярослава Мудрого.

Natalia Satokhina, Candidate of Legal Sciences, Assistant at the Department of Theory and Philosophy of Law, Yaroslav Mudryi National Law University.

e-mail: nataliasatokhina@gmail.com
} 
Спектр проблем, через які було розкрито запропоновану тему, виявився доволі широким: віА найзагальніших аспектів питання про природу права, або праворозуміння (доповіді Є. В. Бурлая, С. І. Максимова, О. В. Петришина, П. М. Рабіновича, С. П. Рабіновича та В. С. Смородинського) та окремих напрямів парадигмальних зрушень у фінософії права (виступи А. О. Бочарова, І. В. Бесаги, В. М. Косовича, О. М. Аитвинова, Н. І. Сатохіної, О. В. Стовби, С. П. Шевцова та Ю. В. Шеляженка) Ао актуальних політичних, технологічнихі культурних викликів сучасній правовій науці (АоповіАі В. О. Абашніка, О. Е. Радутного, Ю. С. Размєтаєвої, О. О. Уварової) і нового прочитання кмасичних питань фінософії та загальної теорії права (виступи К. О. Буряковської, І. С. Загоруя, В. Капліної, А. В. Аук’янова, С. П. Погребняка, О. В. Тарасова).

Статті, які учасники заходу підготували на основі виступів та Аискусій, що їх супроводжували, опубліковані в першому номері журнаку «Філософія права і загальна теорія права» за 2019 рік.

Щирий інтерес наукової спільноти до Круглого столу виАається не випаАковим. Сподіваємось, що цей проект матиме продовження та сприятиме поверненню фундаментальній юриспруденції (фімософії та теорії права) того значення, яке вона повинна мати, аби ми й наАалі могли говорити про право як Аещо реальне. Організатори заходу запрошують усіх бажаючих долучитися до майбутніх Аискусій у стінах Національного юридичного університету імені Ярослава Мудрого і Національної академії правових наук України та на сторінках журнаку «Філософія права і загальна теорія права».

(C) Н. Сатохіна

ОАержано / Received 31.07.2019 